\title{
BAUDRILLARD VE BASIN: FRAKTAL YAŞAMDA GÖSTERININ YENIDEN-ÜRETIMi
}

\section{Baudrillard and Press: The Re-production of Spectacle in Fractal Life}

\author{
Dr. Öğr. Üyesi Eren Ekin ERCAN 2 \\ Üsküdar Üniversitesi, illetişim Fakültesi, Gazetecilik
}

0000-0003-0643-6270

öz

Baudrillard'ın simülasyon kuramı her ne kadar kapitalist topluma dair bütünlüklü bir açıklamayı ele alsa da simülasyonun yeniden üreticisi olarak medyayı merkeze alması oldukça önemlidir. Bu bağlamda Baudrillard'ın kapitalizme, kitleye, medyaya bakışına yaslanarak yapılan bu çalışma Baudrillard'ın basına bakışını konu edinmektedir. Betimleyici yöntemin kullanıldığı çalışmada Baudrillard'ın kitaplarından yola çıkılarak haberi ve gazeteciliği nasıl yorumladığı, işlevsel açıdan toplumsal yapı içerisinde nasıl gördüğünün ortaya konması amaçlanmıştır. Çalışmada ilk olarak Baudrillard'ın oldukça önem verdiği "tüketim" olgusu ve bunun kapitalist toplumdaki izlekleri üzerinde durulmuş, fraktal kavramı üzerinden medyaya dair düşüncelerine yer verilmiş ve sonrasında simülatif imgesellik başta olmak üzere yeniden-üretim aracı olarak basına ilişkin değerlendirmeleri paylaşılmıştır. Çalışmanın en önemli bulgusu, Baudrillard'ın kapitalist sistemi bir bütün olarak görmesi ve basını da bu kapsamda post-gerçek bir kapsamda değerlendirmesidir. Kapitalist sistem içerisinde haber, skandal gerçeklikleri deşifre ettiği ölçüde sisteme inancı arttıran bir niteliğe sahiptir. Çünkü kitleler skandalın haberler aracılığıyla su yüzüne çıkması sayesinde toplumdaki sorunların hallolduğunu düşünmektedir. Oysaki Baudrillard'a göre, tüm skandalların kaynağı kapitalist sistemdir ve haber yalnızca bütünsel (kapitalist) sorunun bir parçasını kitlelere aktarmaktadır. Dolayısıyla haber, sisteme olan edilgen katılımın yeniden üreticisidir.

Anahtar Kelimeler: Baudrillard, Simülasyon, Medya, Basın, Post-gerçeklik

Atıf/Citation: Ercan, E.E. (2021). Baudrillard ve Basın: Fraktal Yaşamda Gösterinin Yeniden-Üretimi. Intermedia International e-Journal, 8(14) 79-92. doi: 10.21645/intermedia.2021.102

\footnotetext{
${ }^{1}$ Makalenin Türü: Derleme Makale / Compilation Article

2 e-mail: erenekin.ercan@uskudar.edu.tr
} 
Extended Abstract: Media and more specifically the press constitute one of the important elements that appear in Baudrillard's reading of capitalist society / system. " An infinite interweaving that he describes as "fractal" and the system in which the part represents the whole and the whole represents the part, has a dynamism based on isolation and reproduces and reproduces things from consumption to politics, from daily life to news. Re-production, on the other hand, has a characteristic that nothing new has been introduced and aims to preserve the existing structure. Re-production reveals this feature through images that do not refer to any reality in a semiotic sense. Therefore, the virtuality in the functioning of this order, which Baudrillard called "simulacra", is a comprehension that has spread to the whole area of life and has been targeted to life / reality and has been "successful" to a great extent.

The biggest producer of images with advertisements, fashion, music and news is the media. In other words, in Baudrillard's theory, media has an important function that reproduces images and ensures that images remain "valuable" and "on the agenda" in a simulative context. The focus of this study is to reveal what the press corresponds to in the imaginary sense in Baudrillard's theory and what function the news has. The descriptive method was used in the study and press, journalism and news facts were discussed and explained within the framework of Baudrillard's views / texts. The importance of the study is that, to my knowledge, it is the first study in the Turkish literature focusing on Baudrillard's views on the press. In the first part of the study, Baudrillard's view of mass culture and consumption is emphasized, in the second part the conceptualization of "fractal" and its relation with the media is tried to be revealed, and in the third and last part, how Baudrillard interprets the news and journalism in the framework of simulation.

According to Baudrillard, the creation of the news simulation is based on his three conceptualizations. These are "fame, image and rings of culture". The phenomena of image and reputation inherited from advertising are reflected in journalists, namely opinion leaders, that the public trusts and values their opinions. What journalists reputed as opinion leaders re-reproduce is that they report the event and put it into context, just like an artist. Because, according to Baudrillard, there are only events in mass communication; It is the communication of the event that creates meaning. An important indicator of this is that no events and facts that are not reported by journalists are ignored by the mass. Therefore, it is the journalists who create the image of the perception of the news that make a political or daily event so "valuable" as news. In a sense, this is not only news, but also the essence of the gaze that emerges in Baudrillard's much broader theoretical approach: If the events and situations were not reproduced by journalists through the medium, the events and situations would be alone. In other words, it seems possible to evaluate it as news = mass. Consequently, it is the news that makes something important in Baudrillard's view. For example, we learn from the news that when there is a war, it is a "war" and how the war that is taking place should be imagined. All this self-targeting semiotic simulation, on the other hand, is permeated from political preferences to consumption habits, from the production of consumption behavior to practices in daily life, and reproduces itself fractally.

Evaluating the scandals in the history of the press as "journalism successes" in this context, Baudrillard points out that the great news of corruption in the political field has a post-truth quality and emphasizes that the real scandal lies in the reproduction of the simulacrum. What appears to be a "journalistic feat" in sight, in fact, covers up the capitalist "scandal" that has spread to all of life and we live in all the time. Countries / masses experience a shock with the scandalous news, and the message is given that there is no scandal anymore, that everything is in order as the scandalous news deciphered the scandal. People think that "immoral politicians" are pushed out of the system, and everyone else gets a more moral outlook directly in the political sense. The published news both ensures the continuity of the system and renews the trust of the masses in the system. The scandalous news is the disclosure of only one of the parts in the fractal structure of the capitalist system. The success of the news is that it "got everyone to believe it was a scandal". In this way, the attention drawn from the whole to the part is reduced to an image in which all the problems of the system are symbolized in the scandal and that can be overcome / survived by castration of the scandal. This also constitutes the essence of Baudrillard's view of journalism as a "successful profession" within the system.

Key Words: Baudrillard, Simulation, Media, Press, Post-truth 


\section{GiRiş}

Jean Baudrillard'ın kapitalist toplum/sistem okumasında beliren önemli sac ayaklarından birini medya ve daha özel olarak basın oluşturmaktadır. "Fraktal" olarak nitelediği sonsuz bir iç içe geçme ve parçanın bütünü, bütünün ise parçayı temsil ettiği sistem, izolasyona dayalı ve tüketimden politikaya, gündelik yaşamdan haberlere kadar şeyleri yeniden ve yeniden üreten bir dinamizme sahiptir. Yeniden-üretim ise esasında ortaya yeni bir şeyin konulmadığı ve mevcut yapıyı korumayı amaçlayan bir bağlama oturmaktadır. Yeniden-üretim bu özelliğini göstergesel anlamda herhangi bir gerçekliğe atıfta bulunmayan imgeler aracilığıyla ortaya koymaktadır. Dolayısıyla, Baudrillardın "simülakr" adını verdiği bu düzenin işleyişindeki sanallık, yaşamın tüm sahasına yayılmış ve yaşamı yani gerçeği hedef edinmiş, büyük oranda da başarılı olmuş bir kavrayıştır.

İmgeler; reklamlarla, modayla, müzikle, haberlerle medyalar üzerinden yayılmaktadır. Farklı bir deyişle Baudrillard'ın kuramında medya, imgeleri yeniden üreten ve imgelerin simülatif bağlamda "değerli" ve "gündemde" kalmalarını sağlayan önemli bir işleve sahiptir. Bu çalışmanın konusu, Baudrillard'ın kuramında imgesel anlamda basının neye karşılık geldiğinin ve haberin nasıl bir işleve sahip olduğunun ortaya konmasıdır. Çalışmada betimleyici (descriptive) yöntem kullanılmış ve Baudrillard'ın görüşleri/metinleri çerçevesinde basın, gazetecilik ve haber olgularının neye karşılık geldiği tartışılış, açıklanmaya çalışılmışır. Betimleyici yöntemle ilgili olarak Hurlburt ve Heavy (2006, s. 77), betimleyici yöntemin aslında bir iç (inner) anlamlılık arayışına odaklandı̆̆ını ve birbiriyle ilişkisizmiş gibi görünen fenomenler arasındaki bağların metinlerarasılık sayesinde tanımlandığını ifade etmektedir. Bu yönüyle çalışmada, Baudrillard'ın kuramı içerisinde basının nasıı nitelendiği ve farklı fenomenlerle nasıl ilişkilendirildiği irdelenmiştir. Çalışmanın önemi, Baudrillard'ın kuramını doğrudan basın üzerinden ele alan ve basınla ilgili görüşlerine odaklanan Türkçe literatürdeki ilk çalışma olmasıdır. Çalışmanın ilk bölümünde Baudrillard'ın kitle kültürüne ve tüketimine bakışı üzerinde durulmuş, ikinci bölümünde "fraktal" kavramsallaştırması ve bunun medya ile ilişkisi ortaya konmaya çalışılmış, üçüncü ve son bölümünde de Baudrillard'ın gazetecilik ve haberi simülasyon çerçevesinde nasıl ele aldığı betimlenmiştir.

\section{Baudrillard'ın Kitle Kültürü Kavrayışı: Tüketim, Tahakküm ve Simülasyon}

Özellikle -Fransızca olarak ilk kez 1981, İngilizce olarak ise 1983 yılında yayınlanan- Simulakrlar ve Simülasyon (Simulacres et Simulation) kitabıyla modern dünyanın kavrayışına ilişkin etraflı bir bakış açısı sunan Jean Baudrillard için medya ve medyanın yarattığı patafizik (düşsel bilim) üzerine düşünmek, bir anlamda toplumsalın kendisi üzerine düşünmek anlamına gelmektedir (Adanır, 2008, s. 9). Bu bağlamda patafizik, bir konfor alanı arayışı olduğu gibi, "içi boşalmış kavramlardan oluşan" simülatif bir mekâna karşılık gelmektedir. Fakat bu konfor alanı, kapitalizmin kesin hâkimiyeti altındaki tüketime dayanan yeniden üretim illüzyonunda kendini kurmaktadır. Kapitalist toplum içinde "devrimci ütopya" olarak beliren bu simülatif gerçeklik, dört temele dayanmaktadır. Bunlar; a) gereğinden fazla ahlaki ve dinin bir uzantısı olarak "bağıs", b) kapitalist toplum yapısı içerisinde romantize edilerek sunulan ve bu nedenle ihlallere kapı aralayan "harcama", c) aynı anda hem bastırılmış hem de serbestlik alanı olarak sunulan bir dinamo olarak "arzu" ve d) tıpkı Tanrı'ya olan borç gibi sistem tarafından yaratılmış olan ve asla ödenemeyen "borç"tur (Baudrillard, 2014a, s. 14).

Emek ve emeğin karşılığını bir türlü alamamanın içinde barındırdığı ütopyacı sahada kapitalizmin tarihsel süreç içerisinde ürettiği tüm bu enstrümanların en büyük başarısını kitlelerin kendi pratikleriyle kendilerini olumsuzlamalarında gören Baudrillard (2016, s. 84-85), bu durumu "simgesel anlamda ölmek" olarak tanımlamaktadır. Simgesel değiş tokuşta kendini yeniden ve yeniden üreten bu ironinin en önemli iki pratiği ise tüketim ve kitle iletişim araçlarının etkisidir. Tüketim, bir anlamda "veren" ve "bağışlayan" olarak iktidarın kendisidir ve tahakkümün zeminini oluşturan mübadeleyi sembolize etmektedir. Farklı bir deyişle, bankaların verdiği krediler, krediler sayesinde borçlandırılan insanlar ve daha sonra ödenemeyen krediler nedeniyle biriken borçların bağışlanıp yeniden düzenlenmesidir. Bu durumun tüketimle ilişikli boyutu, emeğinin karşılığını alamayan insanların bankalarca sunulan "uygun" teklifleri kabul etmelerinde ve olmayan bir parayı tüketim için kullanmalarında yatmaktadır. Özellikle geleneksel kitle iletişim araçları ise tüketim önerileriyle donatılmış ve 
medya içerikleriyle de bunu destekleyen bir tahakküm alanıdır. Böylesi bir yaşamı "yavaş ölüm" olarak yorumlayan Baudrillard (2016, s. 86), devrimsel her türlü çıkışı "ani" ve "beklenmedik" bir hızlı ölüm seçimi olarak görmekte ve iktidarın buna dahi tahammülü olmadığını dile getirmektedir. Özlüce söyleyecek olursak; Baudrillard'a göre kitlelerin tek seçim hakkı vardır, o da yavaş ölmek.

Kitleleri tüm bu tahakkümlerin sonucu olarak "çöldeki sessizlik" olarak gören Baudrillard (2015a, s. 97), sessizliğin arkasında nedeni, kitleleri iktidara yöneltecek sol hareket içindeki kavrayışlarda bulmaktadır. Ona göre, günümüz sol kavrayışının en büyük hatası, araç ile amacı birbirine karıştırması ve bu ikisini çoğu zaman birbirinin yerine kullanmasıdır. Şöyle ki; amaç iktidara gelmeye, araç ise "hiçbir öneme sahip olmayan politik ilke"ye karşlık gelmektedir. Politik ilkeler, sol içerisindeki uzlaşı farklılıklarını ve amacı gerçekleştirmek için yorumsal farklılıklardan doğan sorunsalları kapsamaktadır. Bu nedenle sol, ilahi bir ilke arayışının peşine düşmekte ve aracın kendisi üzerine yapılan tartışma ve mücadeleleri amaçla karıştırmaktadır (Baudrillard, 2015b, s. 12-13).

\begin{abstract}
"Her türlü siyasal şiddete bilinçli bir şekilde son verdiklerinden hemen her yerde hep bu şiddetin kurbanlarına dönüşmekte ve sömürüye dayalı bir iktidarın egemenliği altında yaşayan kitleler denilen o berbat efsaneyi sürdürmekten başka bir şey yapmamaktadırlar. Çektikleri söylevlerin bundan başka bir içeriği yoktur; bu kimden merhamet dilediği, hangi adaletten söz ettiği, kendilerini sermayeden kurtaracak hangi tanrıya seslendiği anlaşılmayan içler acısı ve aptalca bir karşılıklı suçlamaya benzemektedir (Baudrillard, 2015b, s. 13)."
\end{abstract}

Slavoj Zizek'in (2011, s. 46) de "yaptıkları şey ile yaptıklarını düşündükleri şey arasındaki" uçurum şeklinde nitelendirdiği bu çıkmaz, toplumsal anlamda giderek merkezsizleşen bir eleştiriye neden olmakta ve neyi istemediğimizi neyi istediğimizden çok düşünen bir politik vurguyu da kendi içinde taşımaktadır (Zizek, 2013, s. 28). Bu durumun kitlelerde neden olduğu şey, kitlelerin iktidar ve onun belli form ve uygulamalarıyla baş başa kalması olarak karşımıza çıkmaktadır. Ulrich Beck'in (2011, s. 136) deyişiyle "bireyin kendisi, yaşam-dünyasında toplumsalı üretmenin birimi haline" gelmekte ve kırılganlaşan karşı çıkışlara dair her türlü girişim yalnızca "münferit" bir popüler kültür sorunu halini almaktadır. Oğuz Adanır (2008, s. 16), toplumsalın içinin boşaltıldığı ve dolayısıyla toplumsalın olmadığı bu durumu gerçeğin kendisiyle bağların kopması olarak yorumlamaktadır. Ona göre yaşanan şey, modern toplumda gerçeğin biricik varoluş alanı olarak göstergelerin içeriklerini yitirmesi ve kitlelerin "görünümler evrenine" geçmesidir. Görünümler evreninde şeylerin hiçbir anlamı yoktur fakat "onlara anlamları varmış işlemi yapılmaktadır." Bu da bir toplumsaldan çok "toplumsal-ötesi" anlamına gelmektedir. Şöyle ki, kitlelerin kendi gerçeklikleriyle ilişkilerini kaybetmelerinin sonucu olarak gerçekliğe dair göstergeler birer görünüm halini almakta ve sistemin devamlılı̆ıı adına "varmış" gibi yapılmaktadır.

"Gerçek dünya ile birlikte göstergeler dünyasına da bir son verdik" diyen Baudrillard (2015a, s. 63), gerçeklikten simülatif bir hayata geçişin asıl nedenini göstergelerin katledilmesinde görmektedir. Dolayısıyla Baudrillard'a göre modern yaşamda gerçekliğin kendisi doğrudan doğruya göstergelerle eş değerdedir. Baudrillard için göstergenin bağlamsal olarak neyi nitelediğini biraz daha açacak olursak, ona göre "gerçek" ve "göstergeler" diye ikilik içinde dünyayı yorumlamak sorunlu bir kullanımdır. Aksine, modern kitle toplumunda gösterge gerçekliğin temsili olduğu gibi, gerçeklikte yaşamın varoluş̧u anlamda sahiciliğine karşılık gelmektedir. Sahicilik, yaşamın değeridir. Oysa günümüz toplumundaki tek değer tüketim mallarının değeridir ve yaşam yalnızca tüketimle değerli kılınmaktadır.

Ancak bu değerli kılma da simülasyona ilişkin bir varsayımdır. Baudrillard (2009, s. 57-58) bu durumun simgesel değiş tokuşun doğasıyla ilgili olduğunu belirtmekte ve simgesel değiş tokuş sırasında değerli olan şey malların değeri değil, değiş tokuş eyleminde bulunmanın kendisidir demektedir. Konuyla ilgili olarak bir başkasına "armağan" verme eylemini örnek gösteren Baudrillard, armağanla birlikte gerçekleşen değiş tokuşta armağanı veren için de alan için de armağanın ne olduğunun önemi yoktur. Armağan ile, armağanı alan ve veren birbirine 
bağlanmıştır. Armağan edilen şeyin (bir kazak, pantolon, saat vb.) alıcı açııından kullanım değeri de o kadar önemli değildir. Esas olan, armağanla birlikte açığa çıkan simülatif kodlara dayalı duygu durumudur ve tüketimle beliren bu değer anlıktır. Dolayısıyla tüketim, kendini ödüllendirme, kendine armağanlar alma halidir. Armağanın artıkdeğer (surplus) olarak yaratılmış niteliği ve niceliği, yalnızca coşkulanımın şiddetini belirleyen simülatif bir değerdir. Farklı bir deyişle, özneler mallara değil göstergelere sahip olmaktadır. Göstergeler ise malların simgesel değiş tokuş anındaki değerini oluşturan tek gerçekliktir.

Tüketim nesnelerinin göstergesel bir bağlama oturması ise onların sunuluş şekliyle ilgilidir. "Tanım" meselesi olarak tezahür edilen tüketim nesnelerine kazandırılan sıfatlar ve niteliklerin tek amacı, bir anlamda nesnelerin özne seviyesine yükseltilmesidir. Tanım sayesinde özneleştirilen nesneler, bir yandan kullanım değerinden doğan bağlamın üstünü örterken diğer yandan da gösterge düzeyine erişmektedir. Günümüzde tüketim nesnesinin asıl değerini oluşturan şey, nesnelere -reklamlar başta olmak üzere- atanan statülerdir (Baudrillard, 2009, s. 60-62). Bir buzdolabı satın alma pratiği üzerinden örneklendirecek olursak, tüketim nesnelerinin sahip olduğu statüler şöyledir:

"1) Teknik özellikleri ve kullanım amacı nesnenin işlevini belirler. Burada buzdolabı bir cins isimdir.

2) Simge-nesne olabilmesi için buzdolabının bir "özel" isme dönüşmesi gerekir. (Özneyle özdeşleştirilen) böyle bir isim için nesnenin sahiplenilmesi ve tutkuyla sevilmesi gerekmektedir.

3) "Tüketim" nesnesi, bir özel isimden çok genellikle takma bir isme benzeyen bir markaya sahip olmak durumundadır (Baudrillard, 2009, s. 64)."

Nesnelerin statüleşmesi ise ilk bakışta ürünsel çeşitliliğe ve farklılığa dayanıyor gibi görünse de tüm bu çeşitliliğin (farklı model, marka veya işlevsel repertuvar) arkasında, kullanım amacından ve ihtiyaçtan doğan arayış değil, nesnenin kişiselleştirilmesi gayesi yatmaktadır. Böylelikle, tıpkı siyasal alanda olduğu gibi kültürel çeşitlilik nesneler düzeyinde de gerçekleşmiş olmakta ve herkesin beğenisine göre sunulan tüketim nesneleri tam da kişiselleştirilebilmeleri nedeniyle daha "yüce" bir statü kazanmaktadır. "Kültürel sistem"imizin özünü oluşturan bu durum, bir "seçme özgürlüğü"dür. Kaldı ki modern demokratik toplum seçme özgürlüğüne yaslanmakta ve kitleler bu sayede hem kültürel sisteme dahil olmakta hem de kültürel sistemi var etmektedir. Kullanım değeri benzer olan bir nesneye ilişkin olarak sunulan çeşitlilik hem kişiselleştirmeyi hem de seçme özgürlüğünü yaratmaktadır. Çeşit içinden bir tercihte bulunmak ve o tercihin uzantısı olarak satın almak bir seçme özgürlüğüdür. Öte yandan, özgürlüğün göstereni çeşitlilik yani seçmedir. Dahası, seçme aldatmacası göstergesel olarak baskıyı da ortadan kaldırmaktadır. Çünkü hiçbir nesne tek/tektip değildir ve kitlelere dayatılmamaktadır. Fakat bu simülasyonda "asıl önemli olan nokta bizi ekonomik bir düzene boyun eğmeye mecbur eden seçme eylemi", yani kapitalizmin kendisidir (Baudrillard, 2011a, s. 172-174).

Özetle; Baudrillard'ın kitle kavramsallaştırmasının temelini oluşturan şey, birbiriyle ilişikli üç izlek üzerine oturmaktadır. Bunlardan ilki, üretim temelli olarak tarihsel varlığını sürdürmüş olan insanların günümüzde tüketimle kendini tanımlamasıdır. İincisi, Baudrillard'ın tüketimi ele alışıla ilgilidir. Baudrillard için tüketim yalnızca sergilenen basit bir pratik değil, gelişen kapitalizm içerisindeki bir öznenin bir nesneyi diğerine tercih etme nedeninin ardalanında yatan işaret, kod ve imajların mantığını tespit etmek suretiyle kitle toplumunun iç anlamlılı̆ı̆ını yani kültürünü ortaya koymaktır. Üçüncüsü, özünde simgesel değiş tokuşa dayanan tüketimin yarattığı kültürel sistemin ve öznenin özneliğini yok eden kapitalist doğanın simülasyonu üreten dinamiklerini belirlemektir. Tüm bu kavrayışların neticesi ise kapitalist toplumda ölüm ile yaşam arasındaki kesin ayrımın önemsizleşmesidir.

"Simgesel evrende yaşamla ölüm değiş-tokuş edilebilmektedir. Burada terimlerin birbirlerinden kopuk olma yerine tersine çevrilme olanağı sunması değer düşüncesinin sorgulanabilmesini 
sağlamaktadır ki, bilindiği kadarıyla değer, aralarında diyalektik bir ilişki kurulabilen karşıt terimlerin varlı̆ını zorunlu kılmaktadır. Oysa simgesel evrende diyalektik diye bir şey yoktur. Ölüm ve yaşam söz konusu olduğunda örneğin, bizim değerler sistemimizde bir tersine çevrilebilirlikten söz edilemez. Bizim için yaşam pozitif, ölümse negatif bir değere sahiptir. Biz ölümü yaşamın sonu, karşıtı olarak görürken, simgesel evrende bu terimleri birbirleriyle değiştokuş edebilmek mümkündür. Bir başka deyişle ölümün yaşamın yerini, yaşamın da ölümün yerini alabilmesi mümkündür (Baudrillard, 2005a, s. 30)."

\section{Baudrillard ve Medya: Fraktal Yeniden-Üretim}

Kitle iletişim araçları Baudrillard'ın simülasyon kuramında önemli bir yere sahiptir. Baudrillard için medyanın yaptığı şey yalnızca basit bir etkide bulunmanın ötesinde, simülasyonu var eden göstergeler üzerinden yaşamı ve kendiliği algılamanın bütünleştirici bir unsurudur. Medya hem bir arınma hem de şeylere dair gerçeklikten kopmuş göstergeler üzerinden yaşamı anlamlı kılan imaj, kod ve işaretlerin üreticisidir. Baudrillard'ın medyaya ilişkin yorumlarına geçmeden önce, onun simülakr ${ }^{3}$ düzenlerinde medyanın neye karşılık geldiğini irdelemek gerekmektedir.

Baudrillard'a göre (2016, s. 87) "değer yansımasındaki değişmelere" koşut olarak tarihte üç önemli simülakr düzeni vardır. Bunlardan ilki "Rönesans'tan sanayi devrimine" kadar uzanan ve "klasik dönem" olarak bilinen "doğal değer yasası"nın hâkim olduğu simülakr düzenidir. 18. yüzyıla kadar süren bu doğal simülakr düzeninde küçük zanaat girişimleri vardır. Baudrillard'ın bu dönem için "kopyalama"nın esas olduğunu belirtmektedir. Bununla kastettiği ise her şeyin kopyasının orijinal olanın sahtesine karşılık gelmesidir. Örneğin; bir tablo orijinalinin birebir aynısı olarak kopyalansa dahi, orijinal olanın kopyası olması nedeniyle değer görmemektedir. İkinci simülark düzeni "sanayileşme dönemine egemen biçim"dir. Makinenin hâkim olduğu bu dönemin vurgusunu "üretim" oluşturmakta ve gündelik ya da değil aynı üründen seri şekilde üretilmesinin neticesinde eşdeğerlilik söz konusu olmaktadır. Bu dönemde "hakiki" ya da "orijinal" yoktur; yalnızca yenidenüretim vardır. "Yabancılaşmanın altın çağı"nı yaşadığı bu dönemde gerçeküstücü sanatın yükselmesinin nedeni, yükselişte olan bilimsel hegemonyanın gerçekliği göstermek görevini üstlenmesidir. Üçüncü simülakr düzeni ise "kodun belirlediği güncel evre"dir. Bu dönemde "egemen biçim simülasyondur." iletişimsel devrim ve bu devrimin sonucu olarak kitle iletişim araçlarının hegemonya kurması Baudrillard'ın üçüncü simülakr düzenine tekabül etmektedir. Sıradan bir temsil ilişkisinin ötesine geçen simülasyon, bu dönemde hipergerçeklik halini almakta, tarihsel ve ideolojik anlamda bir sonluluğa işaret etmektedir. Sonluluk, simülasyonu aşarak kendi temsiliyetini gerçekliğe kavuşturamamayı temsil nitelemektedir. Kitlelerin nesneleştiği hipergerçek simülakr düzeninde, özne kendisini nesnelerin yerine koyar ve kendisini tutkulu bir şekilde hedef edinir. Dolayısıyla burada klasik sınıf kavrayışından çok, öznelerin özneliklerinden gelen sınıflardan söz etmek gerekmektedir. Baudrillard'a göre dördüncü bir simülakr düzeni daha vardır. O da "fraktal aşama"dır. Öznelerin ve şeylerin birbirinden farksız şekilde boşlukta çoğalıp, yayıldığı bu aşamada nihilizm doruğa çıkmaktadır. O nedenle dördüncü aşamada ölüm, biyolojik bağlamının ötesine geçmekte ve tüm eylem biçimlerinin, karşı çıkışların gösterinin bir mizansenine dönüştüğü, sanallaştığı safhayı ifade etmektedir. Bedenler sanaldır; benzer şekilde para, kültürel alışveriş, savaş, siyaset de. Baudrillard bu aşamada her şeyin transformasyona uğrayarak var olduğunu ve "trans" bir hal aldığını vurgulamaktadır: "Transpolitik, transestetik, transüretken, transseksüel (Gane, 2008, s. 37-39)..."

\footnotetext{
3 "Bir gerçeklik olarak algılanmak isteyen görünüm" anlamına gelmektedir (Baudrillard, 2011, s. 7).
} 


\section{Görsel 1: Farklı şekillerin kopyalanarak/yeniden-üretimle bütün ve parça uyumunu koruduğu fraktallik}
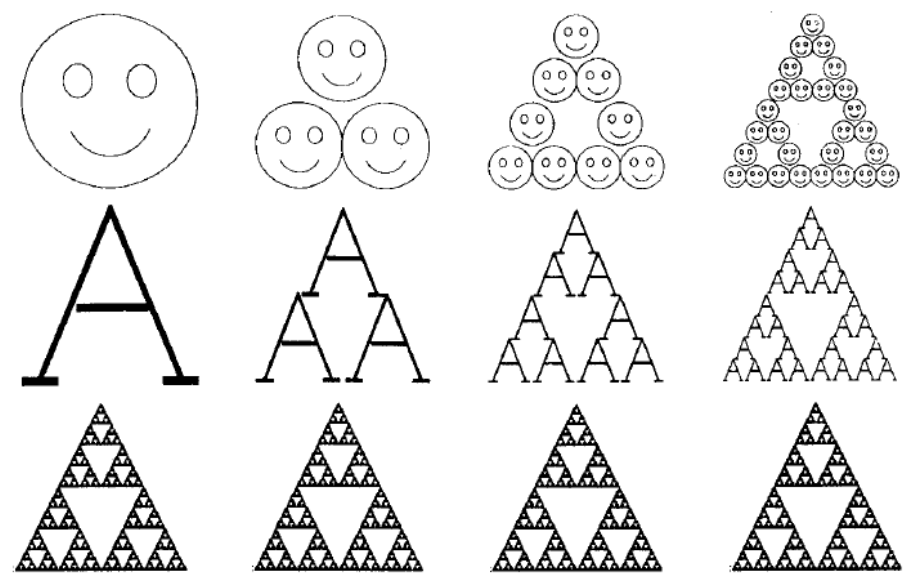

Kaynak: Fisher, 1995, s. 4

Kavram olarak "fraktal" Baudrillard'ın terminolojisinde önemli bir yer tutmaktadır. Matematikçi Benoit Mandelbrot tarafından 1975 yılında ortaya konan terim, kendi içinde aynı biçimin sonsuz kereler çoğaltılabilmesini ve düzensiz gibi görünen bir yapıdaki düzeni betimlemektedir. Baudrillard da $(2005$, s. 63) buradan hareketle fraktal kavramını, günümüz dünyasındaki şeylerin düzenini nitelemek için kullanmaktadır. Ona göre fraktal, "yaşadığımız dünyayı belirleyen temel biçimlerden biridir." Sistemin kendisi mikroskobik parçalardan meydana gelmektedir ve insan da bu zerreciklerden bir tanesidir. Adına ister bilinç ister olgu ister bir haber denilsin, tüm bunlar belirli yerlerde -oluşan yoğunlaşmalar sonucunda- toplanır ve parçalara dağıtılır. Bu parçalar ise çeşitlilik barındırmaktadır. Diğer bir ifadeyle, herkes çeşitlilikten payına düşeni almaktadır. Medya ise bunu, şeyleri "olduklarından daha gerçek şeylermiş gibi" sunarak yapmaktadır. Medyanın etki gücü de burada yatmaktadır: Gündelik yaşam içerisindeki tüm göstergeler medyada kurgu, kamera teknikleri, müzik vb. süreçler sonunda arttııımış bir gerçeklik içinde sunulduğundan, seyircinin/öznenin gerçeklikle ilişkisinde bir yadsınma olmakta ve bu "müstehcen" durum sayesinde özne ile şeylerin gerçekliği arasında kopukluk meydana gelmektedir (Baudrillard, 2005, s. 42-43). Dolayısıyla Baudrillard'a göre, medya bir şeyleri gerçekliğin kendisi olarak sunmaktan öte, gerçekliği artık bir şekilde kitlelerle buluşturmaktadır. Bir çeşit nihilizme neden olan bu durum sayesinde, iletişim bir ihtiyaç olmaktan çıkmakta ve görünürde "kitle" olarak varsayılan olgu, atomize ve parçanın bütünü, bütünün de parçayı yansıttığı simülatif bir biçime bürünmektedir.

Bu anlamda Baudrillard $(2012$, s. 18) için simülasyona neden olan gösterge, dünyayı anlamlandırmamızı sağlayan klasik tanımının dışında, gerçekliği yok eden bir bağlama sahiptir: "Göstergenin en yüce işlevinin gerçekliği ortadan kaldırmak ve aynı zamanda bu kayboluşu perdelemek olduğu bir dünyada yaşıyoruz." ${ }^{4}$ Böylelikle "bakma" ve bunun doğal bir sonucu olan "görme" eylemleri değersizleştiği için, medyada yer alan her şey "görsel olarak emilip yutulma" halini almışır. Kitleler yalnızca gerçekten-daha-gerçek olan gösterge karşıtı göstergeler aracılığıyla süslü simülatif evrene dalmakta ve öznenin gerçeklikle ilişkisi yok edilmektedir.

Baudrillard (2013, s. 28), kitle iletişim araçlarının tüketim toplumu içerisindeki işlevini ise özne üzerinde açığa çıkan bazı gereksinimlerin sonucu olarak görmektedir. Bu gereksinimlerin temelinde, kendi yaşamı başta

\footnotetext{
${ }^{4}$ Konuyla ilgili olarak Guy Debord (1996, s. 36) gösterinin tam da karşıtlıkları içinde barındırmasından dolayı fark edilemediğini ve herkesin gösteriden payına düşeni aldığını belirtmektedir. Debord'a göre tüm bu karşıtlıkların arkasında yatan şey "sefaletin birliği"dir. Bu ise sınıf bilincinin berisinde, birbiriyle çatışan yabancılaşmaların bir sonucudur.
} 
olmak üzere varlığını tanımlamak için girişimde/girişimlerde bulunması zorunluluğu yatmaktadır. Bir türlü girişimde bulunamayan öznede kendini gösteren açmazlar, aynı zamanda tüketimle birlikte gelen hedonizmi/hazzı tehdit eden "edilgen bir suçluluğa" da neden olmaktadır. O yüzden "tarihsiz ve öyle olmaktan mutlu milyonlarca insan için edilginliğin suçluluk duygusundan arındırılması" gerekmektedir. Kitle iletişim araçları da burada devreye girerek dünyaya ve aynı anda kendine karşı suçluluk duyan edilgen kitleleri dramatik unsurlarla şükretmeye zorlamaktadır. Katharsis'ten farkı olarak bu durum, kitle iletişim araçları vesilesiyle bir tatmin olma ve rahatlama halinin ötesinde, öznenin var olan koşullarına şükrederek sadık kalması gerektiğini salık vermektedir. Örneklendirecek olursak, polis ve adliye haberleriyle yaratılan tehlikeli ve kötü dünya hali, özneyi yetinmeci bir çizgiye çekerek girişimden alıkoymaktadır. Bu sayede, tüm bu "kötü ve korkutucu dünya"da özne kendisini "kurtarılmış değer" olarak görmekte ve kendi güvenliği başta olmak üzere özel alanından haz duymaktadır. Eş deyişle, kamusallık/toplum düşüncesi giderek buharlaşmakta ve her birey yalıtılmıs bir simülasyon içerisinde özel alanını ve özel alanında kendisini kutsamaktadır. Böylesi öznelerin toplamı ise kitle toplumunun zihniyetini oluşturmaktadır.

Kitle iletişim araçlarının yarattığı bu yetinmeci kültür, hiçbir şeye sahip olmayan kitlelere yoksunluklarının bulunmadığını düzenli olarak hatırlatan ve onları olumlayan bir simülasyon evrenine davet etmektedir. Baudrillard'ın (2015a, s. 51) "güncel kölelik" adını verdiği olgu, insanlara "neden ve niçin özgür olması gerektiği" arayışını unutturan ve kendi potansiyelini nasıl kullanacağına ilişkin düşünceleri törpüleyen bir bilince neden olmaktadır. Internet medyası -günümüzde özellikle sosyal medya- ise insanlara özel alanındayken büyük bir özgürleşim alanı yarattığı gibi, bir kimlik edinmesini, edindiği kimlik sayesinde sanal girişimlerde bulunmasını ve dilediğince öznelliğini sergilemesini sağlamaktadır. Böylelikle geleneksel medyadan devralınan dünyaya ilişkin suçluluk duyma hali de ortadan kalkmakta ve tüm sorumluluklar sanal ortamda yerine getirildiğinden toplumsal suçluluk nötralize olmaktadır. Dolayısıyla geçmişte olduğu gibi devrimsellik, "insanların kendi varlıklarından endişeye kapılmaları" sonucunda gerçekleşen bir sokağa inme tavrından muaf olmakta ve özgürlük örgütsel değil, tek yanlı olarak yaşanır hale gelmektedir.

Öte yandan, internetin kaotik yapısına da değinen Baudrillard (2015a, s. 70), internetle birlikte "birbirinden farklı şeylerin birbirine karıştığıı" dile getirmekte ve bir bağlam sorununun ortaya çıktığını belirtmektedir. "Mesafeleri ortadan kaldıran internet"in aynı oranda "mesafe bilinci"ni de yok ettiğini ve bunun kimliği esas alan belirsiz bir öznelliğin sonucu olduğunu vurgulamaktadır. Bu bağlamda Baudrillard'ın "Larsen Etkisi" olarak tanımladığı internet, interaktif iletişim çılgınlığının bir sonucu olarak kimlik temelinde herkesin birbiriyle etkileşime geçtiği ve kendi kendisine rezonanslarda bulunduğu bir iletişim atmosferini üretmiştir. Gösterinin yok olmasının aksine herkesin katıldığı bir şenliğe dönüştüğüne işaret eden Baudrillard (2015a, s. 72), internetle ilgili olarak şu soruyu sormaktadır: "Herkesin oyuncu olduğu bir yerde eylem diye bir şey söz konusu olabilir mi?"

Görsel 2: Larsen Etkisi; mikrofon sosyal medya kullanıcısına, amplifikatör sosyal medya platformuna, hoparlör benzer görüşlerin rezonansına karşılık gelmektedir.

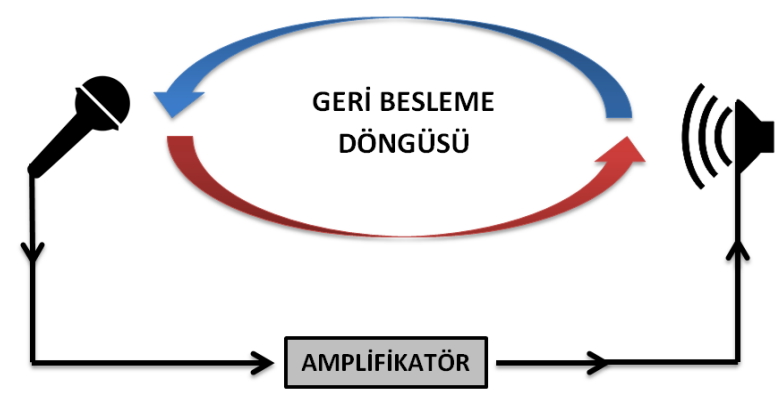


Özlüce söyleyecek olursak, Baudrillard'a göre (2011b, s. 43) medya "gerçek sonuçlarıyla kimsenin ilgilenmediği" yinelenen içeriklerin birbirini eklemlendiği bir işleve sahiptir. Baudrillard'ın "fraktal" dediği bu olgu, "bir amaçtan yoksun hipergerçek ve birbirini doğurup, birbirlerine neden teşkil etmekten başka bir işe yaramayan" olaylar ve durumlar dizgesinin göstergesizliği öne çıkaran göstergeler dünyasında sonsuz bir simülakr düzenini yeniden üretmektedir. En önemli işlevi "caydırma" olan medya, gerçeği daha gerçek kılan senaryolaştırmalara başvurmakta ve hayati bir konudaki olayları dahi geçici kılmaktadır. Bu nedenle özneler özne olamamakta ve adına "sistem" denilen hipergerçek üstbelirlenim bir anlamda "hiç kimseyi" hedef almaktadır (Baudrillard, 2011b, s. 58-60).

\begin{abstract}
"Simülasyon evreni yani görünümler evreni bir caydırma evrenidir. Caydırmanın en önemli silahıysa görüntüler+sözler yani medyadır. Gerçeğin ya da gerçekliğin tamamını görüntü ve sözlere dönüştürerek gerçeği ve gerçekliği teknolojinin yardımıyla safdışı bırakan bu sistem kitleleri bitip tükenmek bilmeyen bir görüntü, ses, yazı vs. bombardımanına tutarak onları ikna etmeye yani kendisinin sağlıklı, güvenilir, başarılı bir sistem olduğuna inandırmaya ve bu inancı ayakta tutmaya çalışmaktadır... Belki de bu medya o sistemde yaşayan insanlardan çok dünyayı bu sistemin hala güçlü, güvenilir, anlamlı, başarılı yani örnek alınabilecek bir model olduğuna inandırmaya çalışmaktadır, kim bilir? Çünkü dünya kendisini göremediği bir sistemi yalnızca görüntü ve üzerine döşenen yorumlar aracılı̆̆ıyla algılamaya mahkûm edilmek istenmektedir (Adanır, 2008, s. 26-27)."
\end{abstract}

\title{
3. Baudrillard, Gazeteler, Gazetecilik: Post-gerçek Anlam(sızık) İnşası
}

Gazeteciliğin ve gazetelerin sürekli bir şekilde "demokrasi" adı altında bir "uzlaşı" mesajı verdiğine dikkat çeken Baudrillard (2013, s. 203-204), "ideal" olarak sunulan böylesi bir modelin esasında önerdiği şeyin, var olan sistemle "yüksek uyuşurluk" şeklinde yorumlamaktadır. Baudrillard'ın "yüksek uyuşurluk" ile kastettiği şey ise, belli bir karakterin öne çıkarılmasıdır. Siyasal ya da devrimsel her türlü karşı duruştan sıyrıımış, tüketimle özgürleşen ve "aktifle pasifin yok edildiği" bir özne halini benimsemiş insanlardır. Haberlerle verilen mesaj, insanların uyum sağlama kapasitesi kadar kendi simülatif gerçekliklerini sürdüreceğidir. Bu bağlamda polis-adliye haberlerine büyük önem atfeden Baudrillard, haberlerde kriminalize edilen insanların geride kalanlara (izleyicilere) verdiği mesajın özünde barındırdığı işlevi, haberde söylenenler de değil söylenmeyenlerde görmektedir.

Haberlerde çizilen "model" insan/sistem, ulaşılacak bir mertebe olmanın ötesinde, kitlelerin içinde bulundukları koşulları kabul etmelerini öneren bir içeriğe sahiptir. Şöyle ki; sahiplik yapısından kurumsal ve siyasal yanlılık sorunsallarına kadar giderek inanılırlı̆ını ve güvenilirliğini yitirmiş olan gazetelerin/gazetecilerin halkın yanında olduğuna ilişkin dillendirilen tarihsel mitos artık ortadan kalkmıştır ve haberlerde olup biten her şey bir simülasyondan ibarettir. Tüm bunlara rağmen haberlerin izlenmesinin nedeni ise haberin/gazetecinin çoğunluğun yanında olduğu mesajının kitle iletişim araçları üzerinden yayılmasında saklıdır. Başka bir ifadeyle, kitle iletişiminin varlı̆̆ı kitleye kitlenin önemli olduğunu aşılayan yapısal bir durumdur. İzleyiciler eş anlı olarak habere konu edilen tekil olayları seyretmekte ve mesajı kitleselleştirmektedir. Bu sayede kitlelere "model sizsiniz, çoğunluk sizsiniz, haber sizsiniz, toplum sizsiniz, olay sizsiniz" denilmekte ve haber/ler aracılığılla gözetim de sağlanmaktadır (Baudrillard, 2011b, s. 54).

Buradan hareketle medium ile mesajın iç içe geçmesinin bir "tersine çevirme simülakrı" yarattı̆̆ını belirten Baudrillard (2011b, s. 55-57), yaşamın ve gerçeğin haberlerin içinde çözüldüğü kadar haberlerin de yaşamın içinde çözüldüğüne dikkat çekmektedir. Toplumsal anlamda en temel değerlerin dahi birer hayali imgeye dönüşmesinin nedeni olan bu demokratik simülakr düzeninde, insanlara atfedilen eleştirel, iyi, doğru, özgürlükçü, demokratik vb. olduklarına yönelik vurgular, iktidarın iktidarını kurma sahasını oluşturan biricik yöntem olarak karşımıza çıkmaktadır. Çünkü günümüzde Orta Çağ'daki gibi bir iktidar ve hükmedilen insanlar değil; her şeyin 
kendi ellerinde olduğu, iktidarın da yine kendisi olduğu, isterse bunu değiştirebileceği mesajını tekrar ve tekrar hatırlatan haberler vardır. O nedenle, izleyiciler/okuyucular iyi ya da kötü her şeyin sorumlusudurlar. ìsterlerse mevcut durumu sandıkta değiştirebilecekleri "yenilenme" arzusu kendi ellerinde olduğu gibi, yeniliğe dair kitlelerin hakkını savunan ve bunu hatırlatan haberler ve gazeteciler de vitrinde, ekrandadır.

Haber simülakrının yaratımı ise Baudrillard'ın üç kavramsallaştırması üzerine oturmaktadır. Bunlar "şöhret, imaj ve kültür halkaları"dır. Reklamcılıktan devralınan imaj ve şöhret olguları, halkın güvendiği ve görüşlerine değer verdiği gazetecilerde yani kanaat önderlerinde karşılı̆ıını bulmaktadır. Kanaat önderi olarak şöhretli gazetecilerin yeniden ve yeniden ürettiği şey, tıpkı bir sanatçı gibi olayı haber haline getirmesi ve bir bağlama yerleştirmesidir. Çünkü Baudrillard'a göre kitle iletişiminde yalnızca olaylar vardır; anlamı yaratan olayın haberleştirilmesidir. Habercilerin haberleştirmediği hiçbir olay ve olgunun kitle tarafından önemsenmemesi bunun önemli bir göstergesidir. Dolayısıyla siyasal yahut gündelik bir olayı haber olacak denli "değerli" kılan da haberin algılanışına ilişkin imajı yaratan da gazetecilerdir. Bu, bir anlamda yalnız haber değil, Baudrillard'ın çok daha bütünlüklü olan kuramsal yaklaşımında beliren bakışın da özüdür: Olayların ve durumların medium üzerinden gazetecilerce yeniden-üretimi olmasaydı, olaylar ve durumlar tek başlarına kalacaktı. Eş deyişle, haber=kitle şeklinde değerlendirmek mümkün görünmektedir. Bu nedenle, Baudrillard'ın bakışında şeyleri şey yapan haberdir. Örneğin, bir savaş olduğunda bunun bir "savaş" olduğunu ve gerçekleşmekte olan savaşın nasıl tahayyül edilmesi gerektiğini bizler haberler sayesinde öğrenmekteyiz. Tüm bu kendini hedef alan göstergesel simülasyon ise siyasal tercihlerden tüketim alışkanlıklarına, tüketimsel davranışların üretiminden gündelik yaşam içeriklerindeki pratiklere kadar sinmiş durumdadır ve fraktal olarak kendini yeniden üretmektedir (Toffoletti, 2014, s. 11-13).

Günün her saatine yayılan, hatta yalnızca "haber kanalı" olarak varlığını sürdüren televizyon kanalları günümüzde yerini internet medyasının olanaklarıyla birlikte yeni bir haber bombardımanına bırakmıştır. Insanların etrafında olup biten şeylerden habersiz olması olası görünmemektedir. Bu durumu tüketim kültürüyle birlikte ele alan Baudrillard (1995, s. 34-35), nasıl ki eşyanın kullanım değerini öldüren talep değil arz patlamasının yol açtığı bir aşırı-üretimden kaynaklanıyorsa, benzer bir durumun haberler içinde geçerli olduğunu belirtmektedir. Tıpkı tüm insanların ömrü boyunca satın alamayacağı ve kullanamayacağı kadar çok eşyanın üretilmesi gibi, haber üretilmektedir. Haberlerin bazıları insanların hayatını "gerçekten" ilgilendiren meseleleri içinde barındırsa da izleyiciler/okuyucular bir diğerine ve oradan da bir başka habere geçmektedir. Haberlerden biriyle ilgili herhangi bir bağlamı oluşturamadan hemen sonra diğeriyle karşılaşmamız, aynı anda iki simülasyonu üretmektedir. Bunlardan ilki, gazetecilerin iyi habercilik yaptığı ve halka haber verme rollerini yerine getirdikleridir. İlkiyle ilişikli ikinci başarı ise basının haberleri halka aktardıktan sonra verecekleri "özgür" kararlardan halkın sorumlu olmasıdır. O nedenle Baudrillard'a göre günümüz toplumunda kriz, bir eksiklikten değil fazlalıktan/aşırılıktan kaynaklanmaktadır. Her şeyin maddi ve manevi anlamda her yerde fazla fazla olması, bir durağanlığa, durağanlık da şeylerin değerli-değersizliğine kapı aralamaktadır.

"Habercilik başarıları" olarak basın tarihine geçen skandalları da bu bağlamda değerlendiren Baudrillard (2011b, s. 32-34), politik alanda gerçekleşen çok büyük yolsuzluk haberlerinin post-gerçek bir nitelik taşıdığına dikkat çekmekte ve asıl skandalın simülakrın yeniden üretilmesinde yattı̆ıına vurgu yapmaktadır. Görünürde bir "gazetecilik başarısı" gibi görünen şey, esasında tüm yaşama yayılan ve her an içinde yaşadığımız kapitalist "skandalın" üstünü örtmektedir. Ülkeler/kitleler skandal haberlerle birlikte bir şok yaşarlar ve skandal haber skandalı deşifre ettiği için artık ortada bir skandal olmadığı, her şeyin böylelikle yoluna girdiği mesajı verilmektedir. İnsanlar, "ahlaksız politikacılar"ın sistemin dışına itildiğini düşünmekte ve geriye kalan herkes doğrudan politik anlamda daha ahlaklı bir görünüme kavuşmaktadır. Ortaya konan haber hem sistemin devamlılı̆ını sağlamakta hem de kitlelerin sisteme olan güvenini tazelemektedir. Skandal haber, kapitalist sistemin fraktal yapısındaki parçalardan yalnızca birinin ifşasıdır. Haberin başarısı "herkesi bir skandal olduğuna inandırmasında" yatmaktadır. Bu sayede bütünden parçaya çekilen dikkatler, sistemin tüm sorunlarının 
skandalda simgeleştiği ve skandalın kastrasyona uğratılmasıyla da atlatılabilecek/kurtulunabilecek bir görüntüye indirgenmektedir.

Gazetecilikteki tarafsızlık olgusunu da değerlendiren Baudrillard (2013, s. 140), keskin bir kapitalist hakimiyetin kurulduğu ve gerçeği aramaya dair tüm ileti ve göstergelerin yalnızca gösterge boyutuyla var olduğu bir dünyada, tarafsız gazeteciliğin aynı oranda "kişiliksiz" bir haberciliğe sahip olduğunu dile getirmektedir. Farklı bir ifadeyle, günümüz dünyasında artık mümkün görünmemesine karşın, eğer bir haber tarafsız ise bu simülakr düzenin etkin bir yeniden-üreticisi olduğu anlamına gelmektedir. Çünkü tarafsız bir habercilik, sistem lehine -ve aynı oranda insanlar aleyhine- her gün önemli değişiklerin yaşandığı bir dünyada "renksizlik" demektir ki, bu da aynı zamanda haberi reklamla ve bunun bir uzantısı olarak tüketimle eşdeğer kılmaktadır. Bu nedenle bir habere "tarafsı" demek, sistemin göstergesel olarak yeniden-üreticisidir demekle aynı anlama gelmektedir.

Kaldı ki Baudrillard'ın (2010, s. 36-37) "imge orjisi" adını verdiği olgu da simülasyonun birer aygıtı/enstrümanı olarak her şeyi eşdeğer tutmaktadır. "Kendini imgelerin bolluğu arkasında saklayan dünya"da sanat, reklam, tüketim, moda, medya, basın vb. her şey, gerçekliği kendi içinde barındırmayan/taşımayan bir "imge bolluğu" üretir. Bir reklam filminde sunulan imge ile bir sanat eserinde yahut bir haberde sunulan imgenin işlevi aynıdır. Tüm bunlar "gerçekliğin aynası" niteliğini taşımadığı için sanal bir gerçekliği yaratmaktadır. Sanal gerçeklik ise kendiliğini yalnızca kendinde taşıyan simülatif bir imge olarak değiştirilememekte ve aşılamamaktadır. Dahası, hiçbir şeyi/gerçekliği yansıtmaması dolayısıyla imgeler var ama kayıptırlar. Bu konuda radyo haberlerini örnek gösteren Baudrillard (2013, s. 139), müzik programının ardından gelen haberlerde dünyanın bir yerinde yaşanan savaşa değinildiğini, ardından ülkeden ölüm haberlerinin verildiğini, sonrasında politikaya dair haberlerle birlikte reklam kuşağına geçildiğini, reklamlarda birbiriyle hiçbir alakası olmayan ürünlerin tanıtıldığını aktarmaktadır. Tüm bunlar hızlı bir şekilde olurken, aralarında ilişkisellik bulunmayan imgeler birbiri ardına gelmekte ve sanallaşmaktadır.

Bu kapsamda haberleri okuma ve izleme pratiğinin başı başına "oyuncul" olduğu üzerinde duran Baudrillard (2014b, s. 198), izleyicinin/okuyucunun bir tanık olmadığını öne sürmektedir. O nedenle bir haberi okuyan/izleyen kişi için o haberin politika, savaş, felaket, sağlık, magazin ya da toplumu ilgilendiren herhangi bir konudaki haber olmasının önemi yoktur. Çünkü kitle iletişiminden yayılan ve birbiri ardına gelen haberler insanlarda belli bir duyarsızlaşma yaratmaktadır. Ek olarak, gazetelerin renkli baskıya geçmeleriyle yahut siyahbeyaz televizyondan renkli televizyona geçişle birlikte "hakikatin 'fazla'laştırılması" sağlandığı için, hakikat teknolojik olarak fazlalaşmış ve aynı ölçüde de hakikate olan mesafe artmıştır. Örneğin, bir bilgisayar oyununun konforlu alanda deneyimlenen gerçekliği, arttırılmış gerçeklikleri (müzik, ses, görsellik vb.) içinde barındırdığından, gerçekten-daha-gerçek olarak algılanmaktadır. Bu bağlamda Giorgio Agamben (2004, s. 17) iki tür tanıklık olduğunu vurgulamaktadır. Bunu da superstes ve testimony kavramlarıyla açıklamaktadır. Superstes "bir şeyi yaşamış, olayı başından sonuna bizatihi kendisi yaşamıs" birincil tanıklığa karşılık gelmektedir. Mahkemelerde üçüncü taraf olarak dinlenen ve Latince terstis'den gelen testimony ise ikincil tanıklı̆ı̆ niteleyen bir kavramdır. Dolayısıyla Agamben, mahkemede olayın bir tarafı olarak superstes'in söyleyeceklerindense testimony'nin söylediklerine göre karar alındığına dikkat çekmekte ve gerçekliği testimony'nin tayin ettiğini belirtmektedir. Baudrillard'ın "fazlalaştırımış hakikat" kavramsallaştırımasındaki durum da buna benzer bir nitelik taşımaktadır. Haberin izleyicileri/okuyucuları yaşamın ve kendilerinin varoluşsal gerçeklikleriyle ilgili gerçekte olan bitenden daha gerçek bir algıya sahiptir. Yaşadıkları dünyada olup biten her şeye, olup bitteni kayda geçiren haberler vesilesiyle ikincil olarak (testimony) tanık olmaktadırlar. Baskı ve yayın kalitesindeki teknolojik gelişmelerin de bu duruma eklemlenmesiyle yaşam, hayatta kalanların hayatta olmalarından ötürü yabancılaşmış bir keyifle- katıldıkları gösterinin içinde kristalize olmaktadır. 


\section{SONUÇ}

Baudrillard'ın yaklaşımından hareketle onun basınla ilgili görüşlerinin tartışıldığı bu çalışmada birbiriyle ilişikli üç temel vurgu noktası öne çıkmaktadır. Bunlardan ilki, Baudrillard'ın içinde yaşadığımız sistemi bütünsel bir şekilde değerlendirmesi dolayısıyla sistem, tüketim ve basın arasında kültürel mantık açısından bağlantılar olduğunu öne sürmesidir. Dahası Baudrillard'a göre medya içerikleri de benzer bir mantık içerisindedir. Örneğin bir reklamda üretilen içerik ile bir haber de ya da bir dizi de üretilen içerik özsel manada aynıdır. Çünkü, medyanın asıl işlevi yaşamın alımlanışına dair göstergeler üretmesidir. Bu göstergeler ise yaşamdan/gerçeklikten kopuk, kendini/yaşamı hedef alan nihilist bir görünüme sahiptir. Kitle toplumunda yaşamın ve yaşam aracılığıyla benliğin yorumlandığı haberler de benzer bir işlev üstlenmekte ve insanları sistemle uyuşum içine sokan bir simülasyonu yaratmaktadır. Bu durumu rıza üretiminden ayıran nitelik, uyuşumun oyuncul/post-gerçek olması yani rızayı üreten inanılırlığın/güvenilirliğin büyük oranda bulunmamasıdır.

İkinci olarak, fraktallik hem sistemin tüm aygıtlarında (din, medya, siyaset vb.) hem de o aygıtlardaki alt katmanlarda (haberler, reklamlar, diziler vb.) benzeş sosyo-kültürel imgeler üretmektedir. Baudrillard'ın deyişiyle "imge orjisi" olan bu durum, birbirinden farklı imgelere karşılık gelmemekte, özünde aynı imgeyi beslemektedir. $\mathrm{Bu}$ ise simülakrın kendisidir. Simülakr, klasik anlamda bir ideolojik vurgunun ötesinde kültürel bir salınımı, herkesin birbirinden izole şekilde atonal bir göstergesiz ölümü kutsadığı simülasyon sahasını nitelemektedir. 0 nedenle simülakrın parçası olan basının tarafıı ya da tarafsız olmasının bir önemi yoktur. Çünkü haber, yapısı gereği yalnızca parçaya odaklanmakta, istese de bütünü odağa alamamaktadır. Kaldı ki fraktallik de bu çıkmazı karşılayan bir bağlama sahiptir.

Üçüncü olarak, kitleler yalnızca tüketim anında özgürdür. Tüketim, basit bir maddi değiş tokuştan ziyade imgesel bir değiş tokuşu betimlemektedir. Bu, bir eşyanın satın alınması olarak görülmesi gerektiği gibi, haberlerin izlenmesi/okunması aracılığıyla asıl gücün kitlelerde olduğu savının tüketilmesi olarak da değerlendirilmesi gereken bir olgudur. Farklı bir ifadeyle, tüketim yaşamı demokratik kılan tek seçenektir ve özgürlük tüketimle eşdeğerdir. Ek olarak, haberleri tüketme özgürlüğü ile tüketmeme özgürlüğü arasındaki ayrım da demokratik bir haktır. Her iki karşıt pratik arasındaki özdeşlik, simülakr düzenini etkilememesinde yatmaktadır. Dolayısıyla, Baudrillard'a göre haberlerden yani haber tüketiminden uzak kalmak "model"den uzak kalmaktır ve bunun "model"e bir etkisi bulunmamaktadır. Çünkü "model"in dışında hiçbir şey yoktur. 


\section{KAYNAKÇA}

Adanır, O. (2008). Simülasyon Kuramı Üzerine Notlar ve Söyleşiler. İstanbul: Hayal Et Kitap.

Agamben, G. (2004). Auschwitz'den Artakalanlar: Tanık ve Arşiv, (Çev. Ali Ihsan Başgül). Ankara: Bağımsız Kitaplar. Baudrillard, J. (1995). Kötülüğün Şeffaflığı: Aşırı Fenomenler Üzerine Bir Deneme, (Çev. Emel Abora ve Işık Ergüden). İstanbul: Ayrıntı Yayınları.

Baudrillard, J. (2005). Anahtar Sözcükler, (Çev. Oğuz Adanır ve Leyla Yıldırım). Ankara: Paragraf Yayınları.

Baudrillard, J. (2009). Gösterge Ekonomi Politiği Hakkında Bir Eleştiri, (Çev. Oğuz Adanır ve Ali Bilgin). Boğaziçi Üniversitesi Yayınevi.

Baudrillard, J. (2010). Sanat Komplosu: Yeni Sanat Düzeni ve Çağdaş Estetik 1, (Çev. Elçin Gen ve Işık Ergüden). İstanbul: iletişim Yayınları.

Baudrillard, J. (2011a). Nesneler Sistemi, (Çev. Oğuz Adanır ve Aslı Karamollaoğlu). Boğaziçi Üniversitesi Yayınevi. Baudrillard, J. (2011b). Simülakrlar ve Simülasyon, (Çev. Oğuz Adanır). Ankara: Doğu Batı Yayınları Baudrillard, J. (2012). Kusursuz Cinayet, (Çev. Necmettin Sevil). İstanbul: Ayrıntı Yayınları.

Baudrillard, J. (2013). Tüketim Toplumu: Söylenceleri/Yapıları, (Çev. Hazal Deliceçaylı ve Ferda Keskin). İstanbul: Ayrıntı Yayınları.

Baudrillard, J. (2014a). Cool Anılar I-II 1980-1990, (Çev. Ayşegül Sönmezay). İstanbul: Ayrıntı Yayınları.

Baudrillard, J. (2014b). Baştan Çıkarma Üzerine, (Çev. Ayşegül Sönmezay). İstanbul: Ayrıntı Yayınları.

Baudrillard, J. (2015a). Şeytana Satılan Ruh ya da Kötülüğün Egemenliği, (Çev. Oğuz Adanır). Ankara: Doğu Batı Yayınları

Baudrillard, J. (2015b). Ilahi Sol, (Çev. Oğuz Adanır). Boğaziçi Üniversitesi Yayınevi.

Baudrillard, J. (2016). Simgesel Değiş Tokuş ve Ölüm, (Çev. Oğuz Adanır). İstanbul: Boğaziçi Üniversitesi Yayınevi. Beck, U. (2011). Risk Toplumu: Başka Bir Modernliğe Doğru, (Çev. Kazım Özdoğan ve Bülent Doğan). İstanbul: İthaki Yayınları.

Debord, G. (1996). Gösteri Toplumu ve Yorumlar, (Çev. Ayşen Ekmekçi ve Okşan Taşkent). İstanbul: Ayrıntı Yayınları.

Fisher, Y. (1994). Fractal Image Compression: Theory and Application. New York: Springer-Verlag.

Gane, M. (2008). Jean Baudrillard: Radikal Belirsizlik, (Çev. Ali Utku ve Serhat Toker). Ankara: De ki Basım Yayım. Hurlburt, R. T. ve Heavey, C. L. (2006). Exploring Inner Experience. Amsterdam/Philadelphia: John Benjamins Publishing Compony.

Toffoletti, K. (2014). Yeni Bir Bakışla Baudrillard, (Çev. Yetkin Başkavak). İstanbul: Kolektif Kitap.

Zizek, S. (2011). Ideolojinin Yüce Nesnesi, (Çev. Bülent Somay). İstanbul: Metis Yayınları.

Zizek, S. (2013). Dünyadaki İsyanların Anlamı, (Çev. Osman Akınhay). İstanbul: Agora Yayınları. 
Etik kurul onayı: Etik kurul onayına ihtiyaç bulunmamaktadır.

Ethics committee approval: There is no need for ethics committee approval.

Bu çalışma araştırma ve yayın etiğine uygun olarak gerçekleştirilmiştir. 